\title{
Chapter 5 \\ Framing in Placemaking When \\ Envisioning a Sustainable Rural \\ Community in the Time of Aging \\ and Shrinking Societies in Japan
}

\author{
Shogo Kudo
}

\begin{abstract}
This chapter examines the concept of rural sustainability in the time of an aging and shrinking society. The chapter first introduces the demographic change that Japan is experiencing, a shift from young and growing population to an aged and declining population. Affected by this change, rural regions are facing numerous challenges affecting living conditions of individuals and downscaling socioeconomic activities at regional and communal scales. The multifunctionality framework is applied to understand the past pattern of rural transition. This allows to illustrate subsequent possible phases in the transition driven by an aging and shrinking population. The chapter then provides a review of the placemaking concept, followed by one case study of a placemaking workshop called Monogatari workshop in Gojome, Akita prefecture, Japan. This case study describes how a group of local youth envisioned the future state of their community. The chapter proposes a conceptual illustration of new perspective that the workshop participants gained. The illustration introduces four types of stories, which are story of the past, story of the present, story of the future, and story of oneself. The workshop provided the process to learn personal and collective memories of particular places from older residents of the town. By reflecting on their stories, the participants discussed how they would like to change the same places in the future. The workshop corresponds to the social capital component in the multifunctionality framework which emphasizes intergenerational ties. The chapter suggest the future research should aim to link intergenerational ties to other two capital components of the multifunctionality framework. By doing so, a vision of stable transition to relocalized system will be established even though rural regions continue to experience aging and shrinking of population.
\end{abstract}

\footnotetext{
S. Kudo $(\bowtie)$

Graduate Program in Sustainability Science-Global Leadership Initiative,

Graduate School of Frontier Sciences, The University of Tokyo, Kashiwa, Chiba, Japan

e-mail: kudo@edu.k.u-tokyo.ac.jp
} 
Keywords Rural sustainability · Placemaking · Aging and shrinking society · Intergenerational ties $\cdot$ Gojome town

\subsection{Introduction}

\subsubsection{Population Aging in Japan and the Challenges in Rural Regions}

Japan has been experiencing a shift from a young population to an aged population. This shift is caused by two major demographic changes, namely aging and shrinking population. In 2016, the proportion of people age 65 and older represents $26.7 \%$ of the population, the highest figure in the world. The proportion of age 65 and older population is predicted to grow to $39.9 \%$ by 2060 (Cabinet Office of Japan 2016). Other evidence of population aging is found in the increase in Japan's median age: 22.2 years in 1950 (Statistics Bureau 2017), and 46.7 years as of 2015. The acceleration of Japan's population aging makes the country's population decline much more prominent. In 2008, the total population of Japan topped at 127.8 million people, the time when Japanese society entered its shrinking phase (Senno 2013).

Recent predictions suggest that the population of Japan will likely decline to 88.1 million people by 2065, a $31.1 \%$ decline from the peak population in 2008 (National Institute of Population and Social Security Research 2017). Because increases in life expectancy and decreases in fertility rates are becoming common demographic transitions in not only developed countries but also in developing countries (Harper 2014), many countries are looking at how Japanese society responds to the emerging challenges of an aging and shrinking society.

Along with the aging trend in many countries, considerable differences are found between urban and rural areas. Among developed countries, population aging is more evident in rural areas than urban areas. Only three OECD countries have a higher elderly dependency ratio ${ }^{1}$ in urban areas than rural areas: Hungary $28.5 \%$, Poland 23.0\%, and Slovakia 20.0\% (OECD 2016). In Japan, the core Tokyo metropolitan area has a $4.6 \%$ lower proportion of age 65 and older population than the average of other prefectures. ${ }^{2}$ This is not caused by a higher fertility rate in Tokyo; in fact, the fertility rate is the lowest in Tokyo, at 1.15 births per woman in 2014

\footnotetext{
${ }^{1}$ Elderly dependency ratio is defined as the proportion of the population aged over 65 to the working-population (commonly defined as the population aged 15-64 in developed countries). Source: OECD 2016.

${ }^{2}$ The core part of the Tokyo metropolitan area consists of Tokyo, Kanagawa, Saitama, and Chiba prefectures. A larger grouping of the Tokyo metropolitan area includes Ibaraki, Gunma, and Yamanashi prefectures (Source: Tokyo Metropolitan Government: http://www.metro.tokyo.jp/ ENGLISH/ABOUT/HISTORY/history02.htm). The average proportion of age 65-plus population of the core Tokyo metropolitan area is $24.3 \%$; the average proportion of other prefectures excluding Tokyo metropolitan area and Okinawa is $28.9 \%$. (Source: percentages calculated from Population Census of Japan 2015)
} 
(Cabinet Office of Japan 2016). However, because of the continual migration of youth population from other prefectures, Tokyo retains its lower rate of older people in its population. In the past, the size of rural-to-urban migration was largest during the country's rapid economic growth in late 1950s to early 1970s. Some 7.15 million people migrated to Japan's three major metropolitan areas of Tokyo, Osaka, and Nagoya in the 30 years from 1954 to 1974. Even today Japan continues to observe a similar pattern of migration to the Tokyo metropolitan area, and the high population concentration is raised as the main cause of economic declines in rural regions (Nihon Sousei Kaigi 2014).

\subsubsection{Discussing Sustainability in an Aging and Shrinking Phase of Society}

Owing to the continuous aging and shrinking of population, Japan's rural regions are facing numerous challenges including those related to living conditions of individual residents (e.g. less accessibility to medical care, infrequent public transportation, loneliness of residents) and the other challenges at the regional societies and communities (e.g. regional economic decline, lack of human resources to assume resource management, community vitality decline). The fact that these challenges are being observed is a sign of social transition from the past phase in which the current economic, social, and political structures were designed to a new phase which requires new social designs. Subsequently, the transition of rural society to an aging and shrinking population phase requires us to re-examine the meaning of sustainability which differs from the topics and scope of sustainability discussed in earlier sustainability science literature.

Since its emergence in the early 2000s, the main focus of sustainability science has been challenges caused by the expansion of human activities such as climate change, land degradation, and energy and resource scarcity. Seminal works of sustainability science state that sustainability science aims to advance our understanding of complex interactions between the ecological system and the human system (Clark 2007; Kates et al. 2001; Komiyama and Takeuchi 2006). Other scholars explain the role of sustainability science in contributing scientific knowledge to sustainable development (Dasgupta 2007; Martens 2006). Aside from these original scopes of the field, sustainability science has the potential of accommodating broader discussions on the normative dimension of the sustainability concept.

Aging and shrinking population poses a question on the way the sustainability concept is understood because the types of challenges these demographic changes deliver are not based on the expansion of human activities. Instead, aging and shrinking of population denote a series of declines in a wide range of social and economic activities. Given the fact that aging and shrinking population will likely remain as a demographic trend of Japanese society in the decades to come, what to sustain becomes unclear. 
Because of a greater degree of aging and shirking population, rural regions in Japan are already facing the possible risk of community closures. Earlier studies addressed rural aging and depopulation on different topics such as the decline of agricultural activities (Ishimaru 2009; Sasaki et al. 2007), general living conditions in remote communities (Niinuma 2009; Noguchi et al. 2010; Takegawa 2010), and revitalization of rural economy by increasing interaction with urban residents (Fujita 2005; Tsutsui et al. 2008). However, what the collection of these challenges implies as a larger social transition has not been well discussed. Moreover, accumulating discussions from various case studies on what rural sustainability means and how local residents try to achieve it is essential to better frame a sustainable society for the future.

\subsubsection{Aim of This Chapter}

This chapter examines the concept of rural sustainability in the time of an aging and shrinking society. This will be achieved by first reviewing the past transition patterns of rural regions based on a multifunctionality framework. This chapter will elaborate how most rural regions have evolved from a farming-based system to a market-based system. The application of the multifunctionality framework allows illustrating subsequent possible phases of rural transition driven by an aging and shrinking population. The chapter then provides a review of the placemaking concept, followed by one case study of a placemaking workshop in the town of Gojome, Akita prefecture, Japan. This case study describes how a group of nine high school students envisioned the future state of their community. The chapter concludes with some discussion on the framings in rural sustainability, and also topics for further studies.

\subsection{Rural System Transition: Multifunctionality Framework}

One core challenge for the rural regions where aging and shrinking populations are omnipresent is establishing a local system that is capable of coping with various forms of changes in the communities. An analysis of the impact of social changes in individual communities is important because residents experience actual changes and organize concrete reactions in their own communities (Holmes 2006; Wilson 2010). Because aging and shrinking populations are changing the quality of communities, a more comprehensive perspective is required to analyze the entire rural system rather than merely addressing topics individually.

Applying a conceptual framework helps anticipate possible future transitions of rural regions. For this purpose, the literature on rural transformation (Amcoff and Westholm 2007; Ilbery 1998) and urban-rural interactions (Caffyn and Dahlström 2005; Dabson 2007; Phillipson and Scharf 2005; Silverstein et al. 2006; Tacoli 1998) is beneficial. Drawing upon these earlier studies based on systems perspective, this study employs a multifunctionality framework to explore future transitions 
of rural regions induced by aging and shrinking populations. The following section introduces the multifunctionality discourse, and describes how it functions as framing in discussing rural sustainability.

\subsubsection{Conceptual Development of Multifunctionality}

The main idea of multifunctionality received a wide range of agreement both from policy makers and academics. Its conceptual development, however, has been diverted and its definition is becoming vague (Andersen et al. 2013; Renting et al. 2009). In many policy-related cases, the definition of multifunctionality has been set individually depending on the purpose of each claim. Regarding this point, Marsden and Sonnino (2008) and Van Huylenbroeck et al. (2007) have provided a comprehensive review on different interpretations of multifunctionality discourse and classified them into three groups: (1) productivist, (2) postproductivist, and (3) sustainable development (Huylenbroeck et al. 2007; Marsden and Sonnino 2008).

The first interpretation of multifunctionality is based on the productivist paradigm which has emerged from a neo-liberalist view of the globalized agricultural market. It realizes the vertical logic and specialization adapted to the globalized market. Multifunctionality in this vision implies the production of multiple outputs from the original inputs provided by primary agricultural production. Such outputs may come in a complementary form to their primary product outputs (Havlik 2005). In this respect, the multifunctional character is limited to the idea of pluriactivity that is formed by agricultural and non-agricultural incomes of farming households (Holmes 2006; Marsden and Sonnino 2008). In the productivist paradigm, individual farming households and the entire agro-food industry are clearly differentiated. Multifunctionality within this paradigm, as a result, is seen as the survival strategy of individual farming households in the global market. As a response to such harsh market circumstances, individual farmers are performing multifunctional agriculture as their coping strategy to keep pace with competition.

The second interpretation of multifunctionality is based on a post-productivist paradigm which focuses on the space of rural areas rather than on production activities. This second interpretation conceives entire rural areas as consumptive targets for amenity demands through eco-tourism, experiencing farm activities, use of rural space for educational purposes, and other means (Barbieri and Valdivia 2010; Huylenbroeck et al. 2007; Marsden and Sonnino 2008; Potter and Tilzey 2005), not only for industrial-based capital. One important actor group in this framing is the urban population who finds scenic and leisure values in rural space. Echoing such normative values of rural areas, the post-productivist view emphasizes environmental protection. Based on this framing, agriculture is perceived as a means of maintaining the local environment of the countryside, not only as a means of food and fiber production. Between the first and second framing in multifunctionality, the conceptual focus shifts from a farm-based approach to a space-based approach through emphasizing the nature and landscape values. 
The third interpretation of multifunctionality takes further expansion from the post-productivist paradigm to a sustainable development paradigm. This third view of multifunctionality takes a holistic framing of the concept to realize the connection between socio-environmental benefits from farming operations and the demands of local societies (Marsden and Sonnino 2008). In this view, multifunctionality is viewed as a critical assessment tool for rural development. In contrast to the previous two paradigms in which the social meanings of rural areas are determined by external interests (e.g. food security concerns, competitive agricultural sector, and environmental protection), this third framing interprets multifunctionality as an inclusive development paradigm that takes the internal socioeconomic state into account (Marsden and Sonnino 2008; Morgan et al. 2010). It should be noted that agriculture is seen as one characteristic of rural areas in this third framing. Because the notion of multifunctionality was initially developed in agricultural policies, the multifunctionality discourse has placed its centrality on agriculture, and other dimensions of rural areas were treated as complementary factors. However, such a narrow framing of multifunctionality hinders depicting the rural system transition. In fact, agriculture is no longer the backbone of rural economies today because its proportion in local economic activities has been declining (Huylenbroeck et al. 2007; Milestad and Björklund 2008). Such economic decline triggered an out-migration of young people in search of better employment opportunities in urban areas (Klijin et al. 2005; Milbourne and Doheny 2012).

The author follows the multifunctionality discussions developed by Holms (2006), Marsden and Sonnino (2008), Renting et al. (2009) and Wilson (2008, 2010). In this chapter, multifunctionality is considered as a holistic conceptual framework that illustrates the quality changes in rural areas over time as rural areas undergo a series of social changes. The applied framework in this study is based on the recent works of Wilson $(2008,2010)$ which depict the quality changes in rural systems in terms of multifunctionality.

In previous empirical studies on multifunctional agriculture, individual farms were used as their analytical unit, and those types of operations that contributed to the multifunctional quality of farmers were examined. These studies commonly set their objectives to quantify the multifunctionality of individual farms by applying parameters (Andersen et al. 2013; Morgan et al. 2010). However, one point of contention is how to select an adequate set of parameters to evaluate the multifunctionality of a target unit quantitatively as the concept of multifunctionality is by no means "clearly and uniformly conceptualized or understood" (Marsden and Sonnino 2008). This view is prominent when a study includes the time-scale because which set of parameters would be appropriate differs according to the socioeconomic state of rural regions over time. Additionally, external factors that possibly affect rural regions are ubiquitous. For example, the state of rural areas before and after the arrival of the global market system should differ from each other considerably. 


\subsubsection{Development of Multifunctionality Framework}

The previous section explained the evolvement of the multifunctionality concept from a framework to evaluate agricultural activities to an all-inclusive concept for rural development. Reflecting the shifts in paradigms over time-from productivist to post-productivist, and to sustainable development-the quality of rural systems illustrates particular transitions, and such transitions represent different qualities of multifunctionality. Based on this idea, Wilson proposes using economic, environmental, and social capitals as a set of descriptive dimensions for depicting diverse qualities of a rural system (Wilson 2008, 2010, 2012). He argues that when the balance of the three capitals is well maintained (well-balanced state in Fig. 5.1), a rural system becomes more stable and achieves self-sustaining capacity. In fact, many rural communities emerged as subsistence farming communities, in which three types of capital were well developed and balanced, and achieved self-managing capacity in producing food, managing local resources, and facilitating minimum exchanges with outside communities.

Illustrating the quality of target systems by sets of indicators has attracted a great deal of research interest across disciplines (Bell and Morse 2008; Morse 2010; OECD 2004; Rametsteiner et al. 2011; Stevens 2005). Wilson provides a solid discussion in studying multifunctionality of rural system with the application of these three types of capital by referring to Bourdieu (1984) to substantiate applying the capital notion (Wilson 2008, 2010). Bourdieu situated capital in three fundamental frames: economic capital (material property), social capital (networks of social

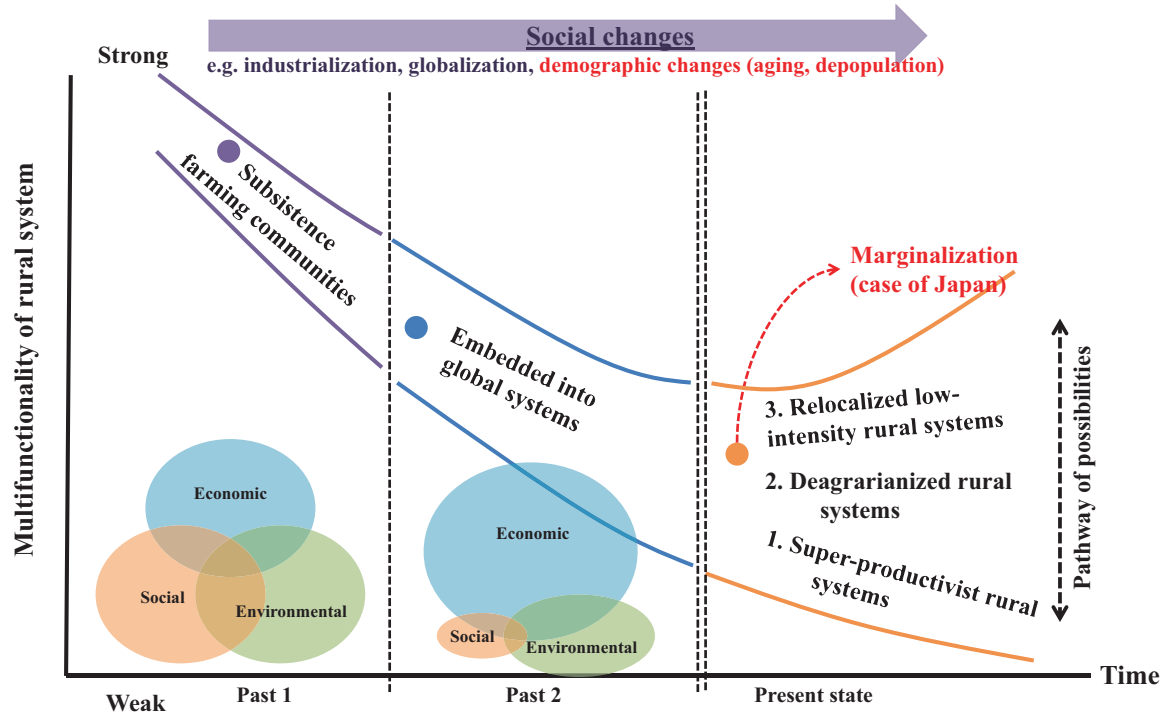

Fig. 5.1 Inter-temporal evolution of the rural system with the quality of multifunctionality. (Source: modified based on Wilson 2008) 
connections and mutual obligations), and cultural capital (prestige) (Bourdieu 1984). In Bourdieu's theory, the notion of capital is used more as a metaphor or description of processes as individuals or groups gain or lose different types of capital through interactions. Following the approach of Wilson and Bourdieu, this study considers the notion of multifunctionality as a metaphor for analyzing the qualitative changes in rural systems.

Once any concentration on a particular capital is created because of the influence of broader social changes (e.g. economic growth, industrialization, urbanization) or internal changes (e.g. demographic change, political system change, resource scarcity), the configuration of the three capitals is affected. When economic capital is emphasized, and as is often the case, through an industrial change from agricultural production to manufacturing, the quality of a rural system shifts towards the superproductivism which is a state of extremely pronounced economic capital (Wilson 2010). In such a situation, the entire rural system loses the social capital and environmental capital, and the share of economic capital expands largely because the national economy and globalized markets as well as the central government's rural policies directly affect the system (Economic-oriented state in Fig. 5.2).

In another situation, when environmental concerns are realized by certain rural policies oriented toward the post-productivist paradigm (e.g. Agenda 21, CAP scheme), the quality of rural systems moves towards a non-productivism (environmental protection) direction and the environmental capital acquires significant attention (see Environmental-oriented state in Fig. 5.2). If the sustainable development paradigm is reflected properly in the rural development scheme, then a sufficient approach to social capital of local communities should be realized; ideally this approach should usher a rural area into the well-balanced state as shown in Fig. 5.2.

The illustrations of the different qualities of multifunctionality based on economic, environmental, and social capital can be applied to an inter-temporal system
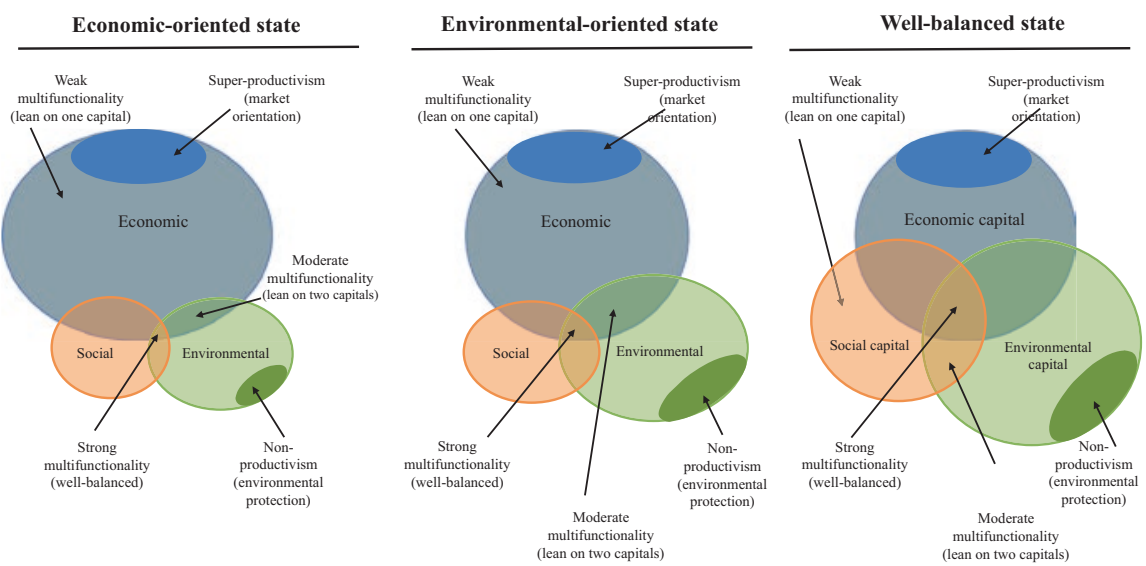

Fig. 5.2 Different quality of multifunctionality based on economic, social and environmental capitals. (Source: modified from Wilson 2010) 
transition model as shown in Fig. 5.1. Venn images are added to represent possible configurations of three capitals that describe each state of rural system transition. The figure depicts two past states of rural system and possible future pathways based on the present. The focal unit of this framework is a rural region and the quality of multifunctionality in each state is described by the totality of all kinds of local resources, attributes of individual residents, and activities taking place. The separations of three states indicate each time period. However, these distinctions are unclear because a system transition occurs over a long time, anywhere from 50 to 100 years perhaps, and is not spontaneous unless a fast and sudden rupture changes the state of system quality dramatically.

The initial state of rural system is described as "Past 1 . Subsistence farming" in Fig. 5.2. In this phase, rural communities are agrarian and self-sufficient in food and generally energy production. The quality of multifunctionality, therefore, appears strong. The three types of capital are considered well balanced at this stage. Such a solid balance is a crucial condition for the survival of a subsistence community.

Once rural communities increase their engagement with the outside world, often when the global market is introduced, a rural system transits to "Past 2. Embedded into global systems" phase (Fig. 5.2). In this phase, the economic capital strengthens to build an economical-oriented system. This transition from subsistence farming to an embedded system tends to drive agriculture toward intensification and monoculture-based production, and causes declines in environmental and social capital because of degradation in the local environment and out-migration of young people (Parnwell 2007; Rigg et al. 2008; Wilson 2010).

The present state, the third state in Fig. 5.2, presents three possible pathways: (1) super-productivist rural systems, (2) deagrarianized rural systems, and (3) relocalized low-intensity rural systems (Wilson 2010). Super-productivist rural systems imply the economic-oriented state in Fig. 5.1, in which the concentration on economic capital is pursued. Towards this direction, approaches based on the productivist paradigm such as intensification and specialization in agricultural production are preferred. The pathway of a deagrarianized rural system initiates a transition to non-agricultural sectors in rural areas. The main goal of deagrarianization is achieving alternative measures to ensure economic capital development in rural systems. The third possible pathway, a relocalized low-intensity rural system direction, aims at a higher multifunctionality quality than the other two pathways by achieving a well-balanced relationship among the three types of capital.

Based on this discourse, the choice of ' 1 ' would lead to a lower quality of multifunctionality in a rural system, and ' 2 ' and ' 3 ' would maintain the same or higher quality. However, these three possible pathways are not separated completely, and in reality, each rural area or community would exhibit the mixed directions through 1-3. At the same time, all rural areas would still be affected largely by the external, broader interests of society. For example, individual communities can direct themselves to a relocalized rural system pathway by conducting local initiatives, whereas the national rural policy can be oriented towards super-productivist to build a competitive agricultural sector in the global market. In fact, the introduction of a market mechanism caused a transition from subsistence farming (Past 1 state in Fig. 5.2) to 
one embedded in the global system (Past 2 state in Fig. 5.2) by increasing economic capital. Towards the future, other changes in larger systems such as national policy reforms, globalization, and demographic changes would predetermine the possible directions of system transition. The possible transitional space is termed as pathway of possibilities as shown in Fig. 5.2 (Wilson 2008).

Apart from the original three pathways, the marginalization pathway is becoming more and more realistic as the fourth possibility for today's rural regions in Japan (Fig. 5.2). The marginalization denotes an excessive degree of qualitative decline in community vitality as well as collective actions of residents in the rural communities (Kudo and Yarime 2013). Community vitality is a relatively new concept and it refers to the ability of a community to "sustain itself into the future as well as provide opportunities for its residents to pursue their own life goals and the ability of residents to experience positive life outcomes" (Crandall and Etuk 2008).

As a rural area enters this marginalization pathway, residents experience declines in various aspects in living conditions such as mobility and access to basic items (Asai et al. 2012; Kuramochi et al. 2014), management of vacant houses and abandoned farmlands (Ishimaru 2009; Shinobe and Miyachi 2012; Yamamoto and Nakazono 2008), and seasonal events and daily chores such as grasscutting in cemetery areas, removing mud and leaves clogging water channels, and cleanups along residential roads (Niinuma 2009; Tamasato 2009). These declines in the communities are considered possible threats to the well-being of residents.

Today, community marginalization is expanding to the small-size municipalities such as villages and towns in Japan, and has ceased to be an issue in rural communities. Knowing aging and shrinking population will most likely drive a rural system to its next transition, it is becoming critical for rural residents to take their own initiatives in responding to the emerging challenges. To implement such initiatives, rural residents must discuss and envision the future they want to have in their own communities. The following section introduces a placemaking workshop conducted with a group of local youths in Gojome, Akita prefecture, Japan, as an example case of such local initiative.

\subsection{Envisioning a Sustainable Community in an Aging and Shrinking Society: Case of Monogartari Workshop in Gojome Town}

\subsubsection{Context}

Gojome is located in central Akita (Fig. 5.3). The town is largely agrarian but also known for its forestry and timber processing industry. The population is 9269 and the proportion of residents age 65 and older is $42.4 \%$ as of October, 2016. Akita has been known as the prefecture with the highest proportion of population age 65 and 


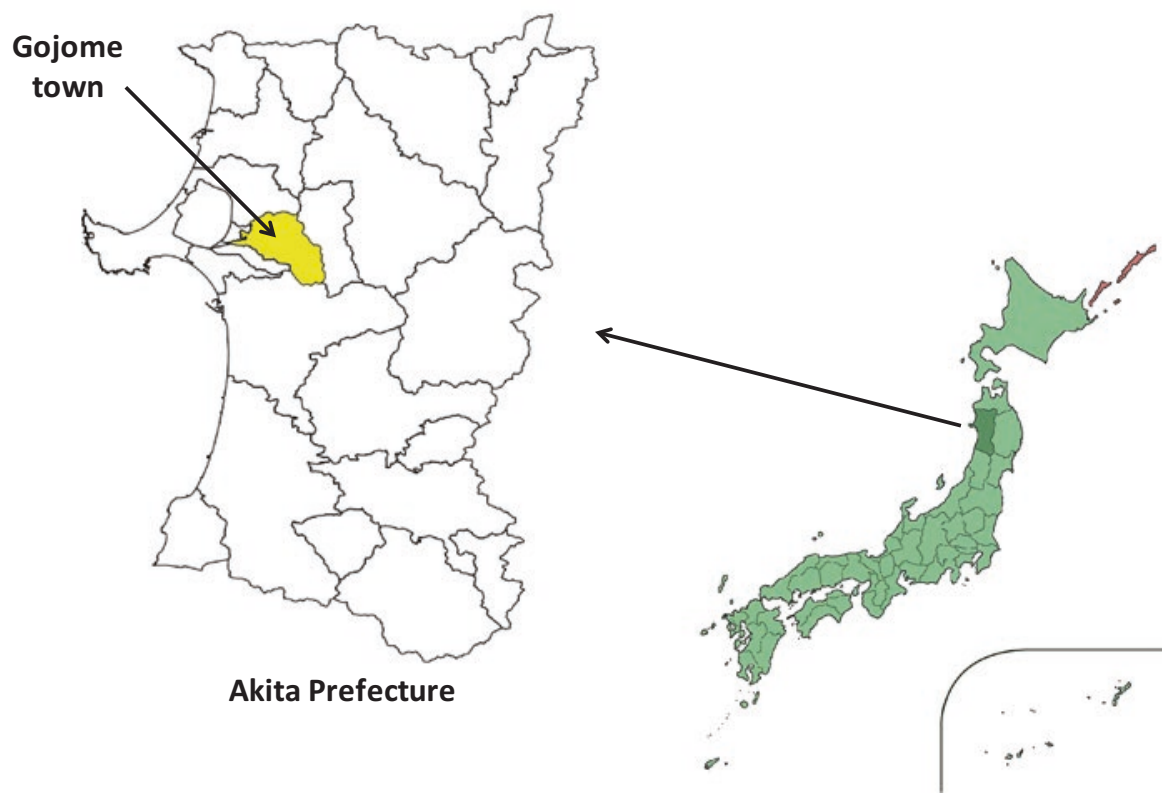

Fig. 5.3 Location of Gojome in Akita prefecture, Japan

over, which was $34.4 \%$ in 2016 , and the highest depopulation rate in the last three census surveys. Gojome is a representative small-size municipality in rural Japan where aging and shrinking population have influenced local communities in terms of its economic, environmental, and social activities.

Figure 5.4 shows population changes of Gojome for 1965-2015, and population predictions until 2040. In 1965, the total population of Gojome was 18,862 people. The town has experienced continual population decline since 1965, and in 2015 the total population was 9433 people, about 50\% of the total population size of 1965 (Fig. 5.4). Subsequently, the share of young people (age 0-15) declined over time: around $20 \%$ in 1980 , but only $7.9 \%$ of the total population today. This continuous decline of local youth further accelerates the aging of Gojome.

One main reason for the town's continuous and constant depopulation is the outmigration of local youth, particularly 15- to 18-year-olds. According to the principal of Gojome Junior High School, the only junior high school in Gojome, only $30 \%$ of graduates choose to go Gojome High School, the only high school in Gojome. The remaining graduates go to high schools in neighboring municipalities. The author and, Ryu Yanagisawa, community development officer in Gojome, had a discussion with the teachers of Gojome High School and shared a concern that the type of education local schools have provided might have influenced the local youth's mindsets to naturally imagine their better future would always be outside the town.

We also shared a concern that the town is losing its next generation of residents who play a key role in sustaining local activities and traditions. The author, Mr. 


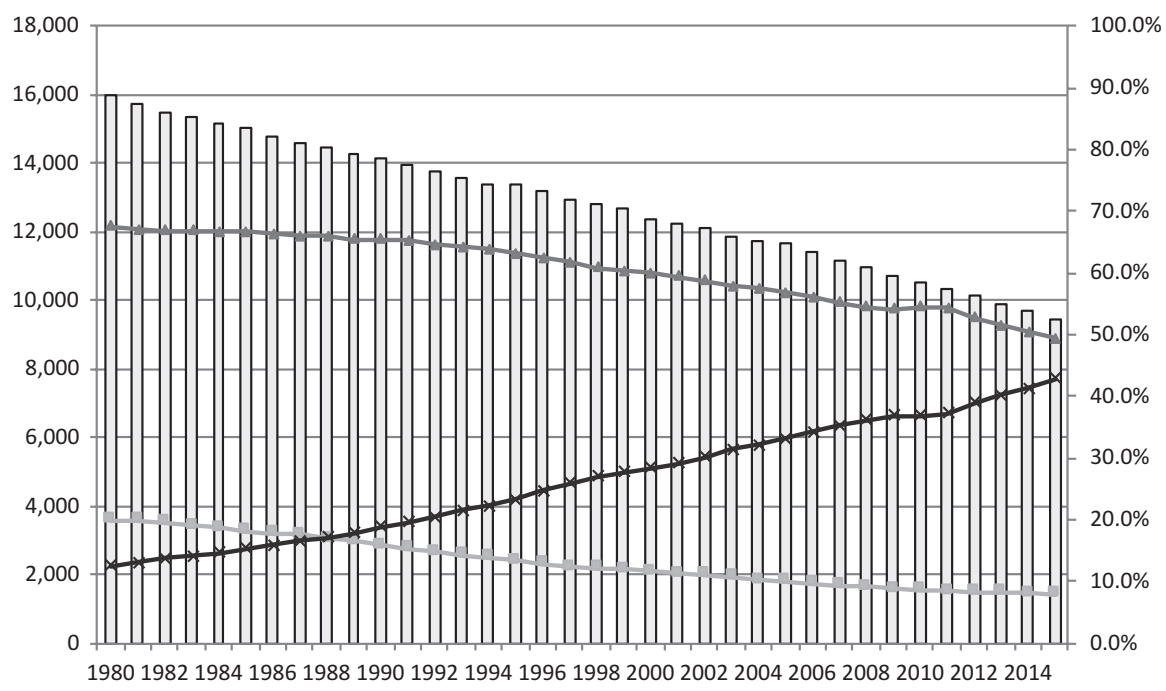

$\square$ Population

$\longrightarrow$-Age 0-15

$\longrightarrow$ Age 16-64

$\rightarrow$ Age 65-plus

Fig. 5.4 Population change of Gojome since 1965. (Data source: Gojome Town Population Vision, 2016)

Yanagisawa, and three teachers from Gojome High School agreed that local youth are an important focus group for the town to train human resources who take initiatives to design the future of Gojome. Based on this common understanding, a workshop targeting a group of nine local youth in the town was conducted.

\subsubsection{Conceptual Design of Workshop: Placemaking Concept}

To develop a workshop for the local youth, the concept of placemaking was utilized. Placemaking has emerged in urban studies and is a process that designs a third place in urban environment. Third place is a concept coined by American urban sociologist Ray Oldenburg and refers to places inside cities where people feel comfortable to be and to socialize with others, which are separately recognized from their home (first place) and their work environment (second place) (Oldenburg 1999). Some examples of third places are cafés, libraries, and art galleries. Oldenburg's argument is that cities need the function of a third place to ensure the well-being of residents. However, in reality, the process of placemaking extends beyond the physical planning of third places; it includes various forms of discussions and negotiations among different stakeholders both in its planning and the actual operation of such third places.

Mitomo (2015), a leading scholar on placemaking concept in Japan, conducted a review on the placemaking concept. Although the covered literature was limited to 
books and reports, she concluded that the concept is ill-defined and concrete implementation steps have yet to be well presented (Mitomo 2015). The author extended the literature review on the placemaking concept to academic journals. A simple online search ${ }^{3}$ found more than 580 journal articles that have "placemaking" in either titles, abstracts, and keywords; however, only a limited number of papers provide clear definitions of the concept. Instead, many of them are empirical studies targeting specific challenges of their case study areas located in different geographical areas. For example, placemaking is applied in studies on community energy projects to understand the social perception and residents' acceptance to energy facility installations (Fast and Mabee 2015; Middlemiss and Parrish 2010).

The concept is also discussed as a possible means for organizing groups of people for social movements (Larsen 2008; Lepofsky and Fraser 2003). Combined with text analysis on social media, placemaking is suggested as a method to realize virtual landscapes in actual city designs (Alkadri et al. 2015). Overall, the review of earlier literature suggests two types of definitions: the conceptual definition, and the working definition.

Regarding the conceptual definition, Pierce et al. (2011) provides a comprehensive definition of placemaking: "the set of social, political and material processes by which people interactively create and recreate the experienced geographies in which they live" (Pierce et al. 2011). In their definition placemaking goes beyond physical planning and requires people's frequent participation in the process. Placemaking is also explained as local responses of the residents of the specific area where particular social issues are present. To structure socially fair and operationally sustainable responses, those particular social issues and places related to the residents need to be framed properly. This process of placemaking is fundamentally linked with how people frame their living environment.

In earlier literature in communication and political science, frame or framing is understood as how individuals organize their experiences and make sense of social events that they encountered (Benford and Snow 2000; Goffman 1974). Framing, at the same time, contributes to recognizing a controversy that resonates with people's core values and assumptions (Nisbet and Mooney 2007). Hence, the placemaking process includes positive, neutral, and negative interpretations of particular social events and associated places. Additionally, along with its affiliation to individuals, framing is generated as the result of collective organizational narratives that reflect the cultural values of people (Benford 1997).

Considering neighborhood and communities as its focal point, placemaking is fundamentally a collective process by a group of residents. Through framing, people judge what issues are relevant to them and what issues are not, who should be responsible for the issues, and what actions should be taken (Gamson et al. 1992; Price et al. 2005). Through this process, placemaking guides us to re-examine the framings that people hold of living environment through organizing a

\footnotetext{
${ }^{3}$ This search was conducted on 20 November 2016 in Science Direct and Google Scholar. The search was conducted by using "placemaking" as the keyword specified in title, abstract, and keyword list. The search resulted in 581 hits in Science Direct and 588 hits in Google Scholar.
} 
series of dialogues among residents and collectively envision a desirable future state of community.

Regarding the working definition, Placemaking Chicago, a well-respected NGO involved in urban planning, provides a clear definition of placemaking:

"Placemaking is a people-centered approach to the planning, design and management of public spaces. Put simply, it involves looking at, listening to, and asking questions of the people who live, work and play in a particular space, to discover needs and aspirations. This information is then used to create a common vision for that place. The vision can evolve quickly into an implementation strategy, beginning with small-scale, do-able improvements that can immediately bring benefits to public spaces and the people who use them." $*$ underlining added by the author for emphasis.)

Project for Public Spaces based in New York, another well-respected organization working on urban development, adds that placemaking is to "inspire people to collectively reimagine and reinvent public spaces as the heart of every community" (Project for Public Space 2016). Several other NGOs based in English-speaking countries work for the implementation of placemaking concept to solve local challenges. All of these organizations emphasize the participation of residents in the process of placemaking.

By integrating the conceptual definition of scholars and the working definition of practitioners, this study defines placemaking as the collective social, political, and material processes planned and implemented by a group of people who reside in a particular place to envision the future state of their communities. These processes include a series of formal and informal gatherings in which a wide range of topics and methods to realize their desirable form of community are discussed.

\subsubsection{Practice: Monogatari Workshop}

The workshop was organized for 2 days in August 2016. By applying a Japanese expression of "stories" (monogatari), the workshop was entitled Monogatari Workshop. The objective was to elicit stories about places in the town of Gojome about which people have personal or collective memories. This workshop corresponds to the beginning of placemaking process, re-examining people's understanding about the environment in which they live in. Nine students from Gojome High School participated, including two local residents: one man in his early 50s and another man in his early 60s served as key informants for the interviews included in the workshop.

Photography was utilized as the main method of this workshop. Firstly, old pictures taken 50-100 years ago in Gojome were used during the interviews to enable the informants to recount stories of the past (Fig. 5.5). By asking key informants questions about the events, items, and activities shown in those pictures, the participants learned the lifestyle of people in the past (Fig. 5.6). The two adult residents 


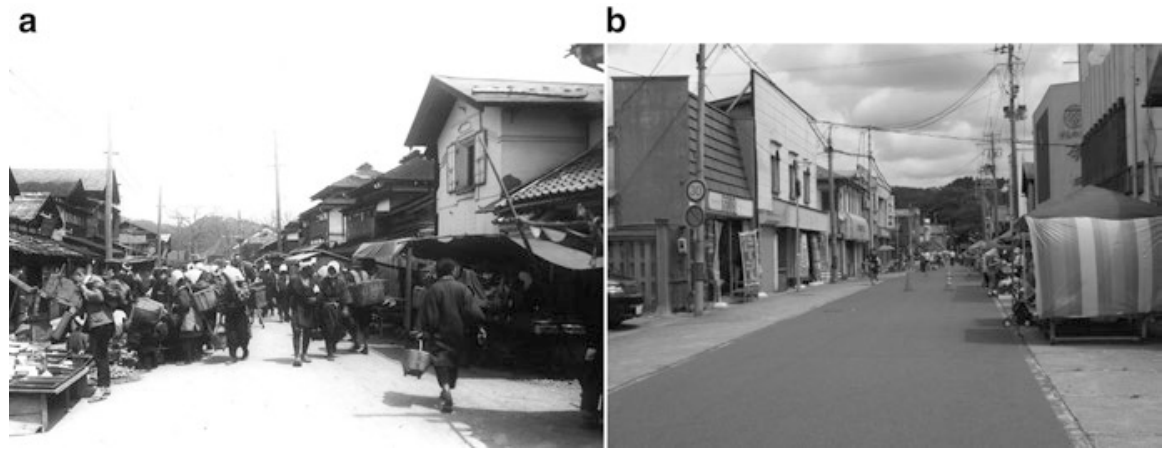

Fig. 5.5 (a) Street market (ca. 1930). (b) Street market (2016)
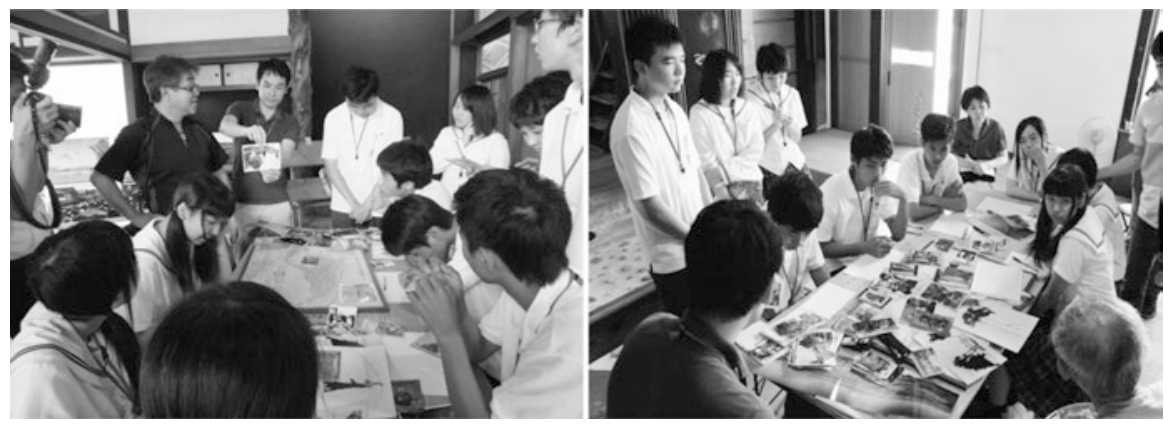

Fig. 5.6 Interviewing two local residents

who participated as key informants were owners of a bookstore and a photo studio. Some of the workshop participants found the pictures of the local farmer's market interesting because many changes were identified such as people's clothing, items they were selling, and the crowdedness of the market.

Secondly, after learning the stories of the past from the interviews, the participants each chose one picture and visited the same location to observe buildings, landscape, and people's activities of today. By identifying landmarks at each place such as old walls, power line poles, and mountain scenery, the participants took pictures from an angle that best approximated the same angle in the old pictures. They also walked around the place in the old pictures and observed the activities taking place today. When encountering some people in the area, they interviewed them to collect information about those places. Through this process, the participants gained a better understanding of the places they had chosen in two different points of time. This activity helped the participants perceive the Gojome of 2016 

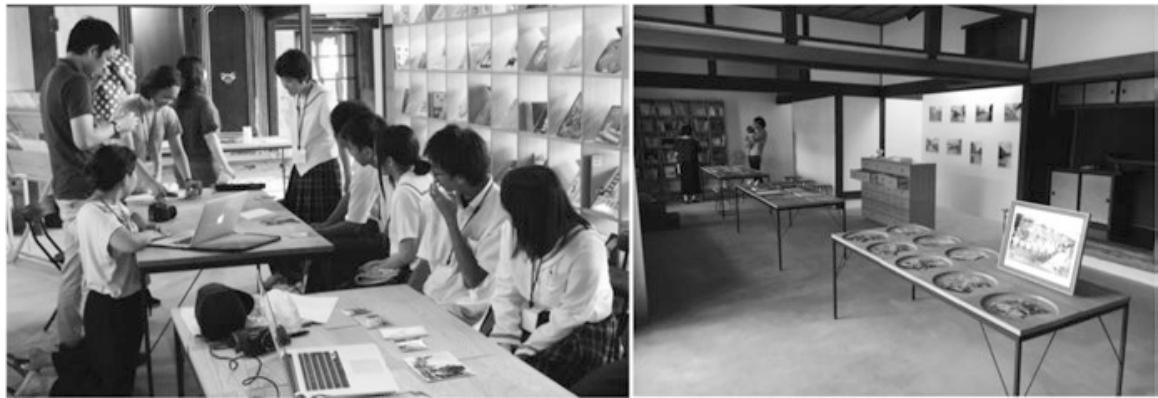

Fig. 5.7 Reporting findings and final exhibition

based on how places were used by people in the past, not only on how places look like today. Such in-depth understanding about places in their town allowed them to re-examine the value of places today.

Thirdly, after taking the picture of today at the same locations as in the old pictures the participants had chosen, the participants shared the stories of the past and the present. They described the old pictures they chose, shared what they found interesting in the old pictures, and how they felt by visiting those places. By utilizing old pictures and the pictures participants took by themselves on the day of workshop, the participants discussed what kind of community they want to actualize in the future. This last process corresponds to the process to collectively envision the future state of community in placemaking (Fig. 5.7). Pictures taken by the workshop participants and the old pictures used during the interview were exhibited with some explanatory notes at a local community center. This exhibition was for Gojome residents who wanted to learn the changes in places in the town and who wanted to join the placemaking process.

Through this workshop, the participants obtained a new perspective to envision their future through learning three stories about their local places and sharing his or her fourth story with other participants. The first one is the story of the past from the interviews. This process raised awareness of the participants regarding how places looked in the past and what kinds of activities were conducted then.

The second narrative is the story of the present. The picture-taking activity and interviews at the same location as in old pictures provided multiple understandings about local places. All participants mentioned that they paid little attention to how places have changed over time prior to this workshop. By learning those changes from the past to the present, participants gained the story of today.

The third story provided insights into what may come, the story of the future. This was created collectively by workshop participants through sharing their ideas for the desirable future state of the places they have learned through the workshop.

Additionally, we also discussed what individual participants can do to actualize the envisioned future of local communities. Interestingly, most of the participants expressed that they would like to preserve the current landscape, features, and activities of the places they studied for their future instead of creating new activities. 


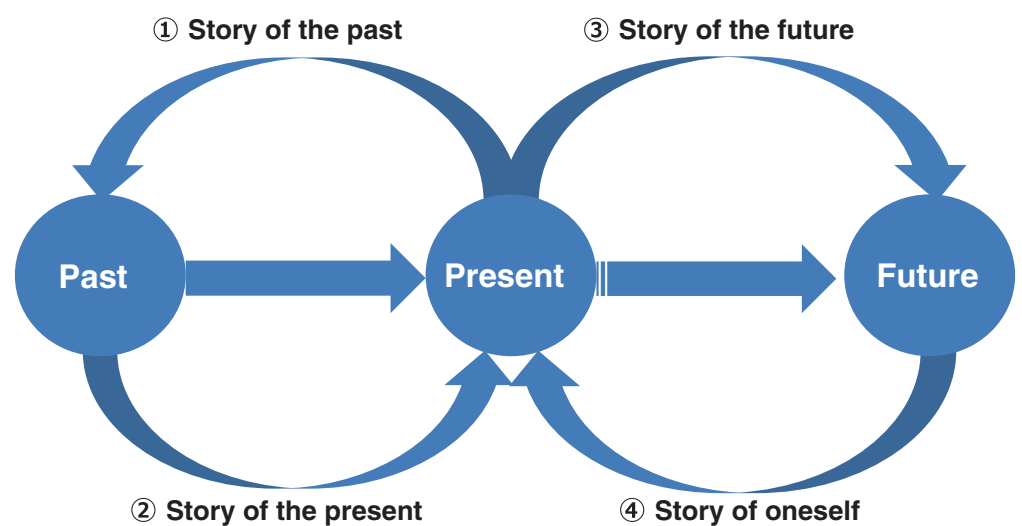

Fig. 5.8 Participants new perspective gained through Monogatari workshop

Finally, as the fourth story, each participant reported how they would like to react to the third story they discussed. Summarizing each participant's report to develop a concrete action plan is not the intention of this step. Instead, acknowledging others' ideas for actual reactions to what they learn is the goal of this last step. Figure 5.8 summarizes the perspective participants gained through this workshop. This infinitysymbol-like shape perspective illustrates a retrospective view when envisioning the future based on the present and the past. Instead of directly perceiving the present from the past and anticipating the future from the present, workshop participants took four stories as steps to deepen their understanding about the past, the present, and a possible Gojome of the future. The fourth story they reported was the story of oneself, which inquires what the participant would do as an individual member of the local community at the present moment to actualize the discussed desirable future through workshop.

\subsection{Concluding Discussion}

Reflecting on the previous sections, two major discussion points on framing involved in rural sustainability in an aging and shrinking society arose. The first point is a macro-scale framing in rural transition and how a rural region can be directed to a sustainable development pathway. The multifunctionality framework described past transition patterns of rural systems and provided three possible directions of system transition pathways driven by various social changes. The past transitions were largely caused by global market mechanisms and the increased awareness of environmental protection. The sustainable development notion is claimed as a recent driver of rural system transition; however, its reflection of reality is often limited to the policy level such as the Common Agricultural Policy (CAP) scheme in Europe. 
This chapter argues that aging and shrinking population has emerged as prominent driver of system transition and is accompanied by the fourth possible direction of transition, the marginalizing pathway. Rural areas of Japan are the most typical cases where such transition is taking place. The emergence of marginalization pathways is inevitable because the total population of the country is in a long-term trend of an aging and shrinking population. When such a declining pathway is suggested, the meaning of rural sustainability becomes increasingly nebulous and must be redefined.

In extension of the first point, the second discussion point concerns the process for deciding what to sustain in rural communities in the time of aging and shrinking societies. This is a critical framing issue on what people as a society aim to sustain in rural regions and what rural residents want to sustain in their own living environment. Multifunctionality framing notes that scenic and leisure values in natural landscape, and historical and cultural values, are to sustain in rural regions. This argument has been the main justification for rural policies that provide a wide range of support to rural regions, particularly through agricultural policies, both in Europe and Japan. However, this line of discussion is rather top-down and situates rural residents as the stewards of the regional assets, which national policies consider important.

More importantly, the voices of rural residents are not well-reflected and the ownership of discussion is missing. Placemaking serves as a bottom-up approach to initiate discussion among rural residents to redefine their understanding to living environment and to identify what residents want to sustain in their own communities. Furthermore, the placemaking process guides the participants to collectively envision a desirable state of their own communities in the future. This participatory process generates a new mindset among the participants to engage with local issues. This chapter introduced a Monogatari placemaking workshop in Gojome, Akita prefecture, Japan which trained nine high school students in the town to have a retrospective view to reframe their understanding of local places and history. Such an interactive process is an integral part of the core of placemaking and helps the participants commit themselves to the ownership of present-day local challenges.

To conclude, discussing rural sustainability in an aging and shrinking phase of society emphasizes the importance of intergenerational ties. In such aging and shrinking communities in rural Japan like Gojome, identifying a method to lead their community to the relocalized low-intensity rural systems direction is critical (see "3. Relocalized low-intensity rural systems" in Fig. 5.2) because this can ensure the highest degree of multifunctionality. This is also desirable because the most stable state of a rural system is achieved. This study suggests placemaking as one method to lead a rural region towards this direction. The workshop contributed to creating intergenerational ties about different places in Gojome through learning four different stories namely story of the past, story of the present, story of the future, and story of oneself (Fig. 5.8).

The workshop provided the process to learn personal and collective memories of particular places from two local residents in different generations. By reflecting on their stories, the participants discussed how they would like to change the same places in the future. This practice addressed the social capital component in the multifunctionality framework. The next step for the author is to expand intergenera- 
tional ties to the other two capitals in the multifunctionality framework. By doing so, a vision of stable transition to relocalized system will be established among the local residents even though rural regions continue to experience aging and shrinking of population.

\section{References}

Alkadri MF, Istiani NFF, Yatmo YA (2015) Mapping social media texts as the basis of place-making process. Procedia Soc Behav Sci 184:46-55. https://doi.org/10.1016/j.sbspro.2015.05.052

Amcoff J, Westholm E (2007) Understanding rural change demography as a key to the future. Futures 39(4):363-379. https://doi.org/10.1016/j.futures.2006.08.009

Andersen PS, Vejre H, Dalgaard T, Brandt J (2013) An indicator-based method for quantifying farm multifunctionality. Ecol Indic 25:166-179. https://doi.org/10.1016/j.ecolind.2012.09.025

Asai H, Kawasuso T, Oura F (2012) Tottori-ken ni okeru Kaimono Jyakusha Taisaku ni kansuru Torikumi - Chukan Chiiki no Kaimono Jyakusha Taisaku ni kansuru Kisoteki Kenkyuu Sone 1 [鳥取県における買い物弱者対策に関する取り組み-中間地域の買い物弱者対策に関 する基礎的研究その1 ]. J Archit Build Sci 1:163-164

Barbieri C, Valdivia C (2010) Recreation and agroforestry: examining new dimensions of multifunctionality in family farms. J Rural Stud 26(4):465-473. https://doi.org/10.1016/j. jrurstud.2010.07.001

Bell S, Morse S (2008) Sustainability indicators measuring the immeasurable, 2nd edn. Earthscan, Abingdon

Benford RD (1997) An insider's critique of the social movement framing perspective. Sociol Inq 67(4):409-430. https://doi.org/10.1111/j.1475-682X.1997.tb00445.x

Benford RD, Snow DA (2000) Framing processes and social movements: an overview and assessment. Annu Rev Sociol 26:611-639. Retrieved from http://www.jstor.org/stable/223459

Bourdieu P (1984) Distinction: a social critique of the judgement of taste. Routledge, London

Cabinet Office of Japan (2016) Kourei Shakai Hakusho (White paper report on the aging society 2016 高齢社会白書2016). Tokyo. Retrieved from http://www8.cao.go.jp/kourei/ whitepaper/w-2016/zenbun/28pdf_index.html

Caffyn A, Dahlström M (2005) Urban-rural interdependencies: joining up policy in practice. Reg Stud 39(3):283-296. Retrieved from http://www.tandfonline.com/doi/ abs $/ 10.1080 / 0034340050086580$

Clark WC (2007) Sustainability science: a room of its own. Proc Natl Acad Sci U S A 104(6):17371738. https://doi.org/10.1073/pnas.0611291104

Crandall M, Etuk L (2008) What is community vitality? Retrieved August 17, 2015, from http:// oregonexplorer.info/content/what-community-vitality

Dabson B (2007) Rural-urban interdependence: why metropolitan and rural america need each other. The Brookings Institution, Washington, DC

Dasgupta P (2007) The idea of sustainable development. Sustain Sci 2(1):5-11. https://doi. org/10.1007/s11625-007-0024-y

Fast S, Mabee W (2015) Place-making and trust-building: the influence of policy on host community responses to wind farms. Energ Policy 81:27-37. https://doi.org/10.1016/j.enpol.2015.02.008

Fujita Y (2005) Komyuniti Bijinesu ga Kirihiraku Chiiki-zukuri [The potential for regional development through community business コミュニティビジネスが切り開く地域づくり]. Tottori Univ J Fac Reg Sci 2(1):11-27

Gamson WA, Croteau D, Hoynes W, Sasson T (1992) Media images and the social construction of reality. Annu Rev Sociol 18:373-393

Goffman E (1974) Frame analysis: an essay on the organization of experience. Northeastern University Press, Boston 
Harper S (2014) Ageing societies. Routledge, London

Havlík P (2005) Joint production under uncertainty and multifunctionality of agriculture: policy considerations and applied analysis. Eur Rev Agric Econ 32(4):489-515. https://doi. org/10.1093/erae/jbi027

Holmes J (2006) Impulses towards a multifunctional transition in rural Australia: gaps in the research agenda. J Rural Stud 22(2):142-160. https://doi.org/10.1016/j.jrurstud.2005.08.006

Huylenbroeck G Van, Vandermeulen V, Mettepenningen E, Verspecht A (2007) Multifunctionality of agriculture: a review of definitions, evidence and instruments. Living Rev Lands Res 1(3). https://doi.org/10.12942/lrlr-2007-3

Ilbery B (1998) The geography of rural change, 2nd edn. Routledge, Abingdon, Oxon

Ishimaru N (2009) Genkai shuraku to iwarete iru shuraku ni okeru 耕作放棄地に関する研究 [A study on the situation of abandoned cultivated land in the village, so-called squeezed village - in a case of Soradani district, Aki-Oota-cho, Hiroshima Prefecture]. Architect Inst Jpn NII Electron Libr Serv 32:4

Kates RW, Clark WC, Corell R, Hall JM, Jaeger CC, Lowe I, McCarthy JJ, Svedin U (2001) Sustainability science. Science 292(5517):641-642. https://doi.org/10.1126/science.1059386

Klijn JA, Vullings LAE, Lammeren RJA van, Meijl H van, Rheenen T van, Veldkamp A, Verburg PH, Westhoek H, Eickhout B, Tabeau AA (2005) The EURURALIS study: technical document. Alterra. Retrieved from http://library.wur.nl/WebQuery/wurpubs/343642?wq_sfx=wever

Komiyama H, Takeuchi K (2006) Sustainability science: building a new discipline. Sustain Sci 1(1):1-6. https://doi.org/10.1007/s11625-006-0007-4

Kudo S, Yarime M (2013) Divergence of the sustaining and marginalizing communities in the process of rural aging: a case study of Yurihonjo-shi, Akita, Japan. Sustain Sci 8(4):491-513. https://doi.org/10.1007/s11625-012-0197-x

Kuramochi H, Tanimoto K, Tsuchiya S (2014) 中山間Chiiki ni okeru Kaimono Shienni kansuru Kosatsu - Ido Hanbai ni Kosatsu - Ido Hanbai ni Chumoku shite - (Shopping support in rural depopulated areas: focusing on delivery services). Sociotechnol Res Netw 11(April):33-43

Larsen SC (2008) Place making, grassroots organizing, and rural protest: a case study of Anahim Lake, British Columbia. J Rural Stud 24(2):172-181. https://doi.org/10.1016/j. jrurstud.2007.12.004

Lepofsky J, Fraser JC (2003) Building community citizens: claiming the right to place-making in the city. Urban Stud 40(1):127-142. https://doi.org/10.1080/00420980220080201

Marsden T, Sonnino R (2008) Rural development and the regional state: denying multifunctional agriculture in the UK. J Rural Stud 24(4):422-431. https://doi.org/10.1016/j. jrurstud.2008.04.001

Martens P (2006) Sustainability: science or fiction? Sustain Sci Pract Pol 2(1):36-41

Middlemiss L, Parrish BD (2010) Building capacity for low-carbon communities: the role of grassroots initiatives. Energ Policy 38(12):7559-7566. https://doi.org/10.1016/j.enpol.2009.07.003

Milbourne P, Doheny S (2012) Older people and poverty in rural Britain: material hardships, cultural denials and social inclusions. J Rural Stud 28(4):389-397. https://doi.org/10.1016/j. jrurstud.2012.06.00

Milestad R, Björklund J (2008) Strengthening the adaptive capacity of rural communities: multifunctional farms and village action groups. In: Proceedings of the 8th European IFSA symposium, July, pp 6-10. Retrieved from http://ifsa.boku.ac.at/cms/fileadmin/Proceeding2008/2008_ WS3_02_Milestad.pdf

Mitomo N (2015) Puresumeikingu no teigi gensoku to ba no hyouka koumoku ni kansuru kousatsu. [プレスメイキングの定義原則と場の評価項目に関するる 察] 日本デザイン学会デザ イン学研究

Morgan SL, Marsden T, Miele M, Morley A (2010) Agricultural multifunctionality and farmers' entrepreneurial skills: a study of Tuscan and Welsh farmers. J Rural Stud 26(2):116-129. https://doi.org/10.1016/j.jrurstud.2009.09.002

Morse S (2010) Sustainability: a biological perspective. Cambridge University Press, Cambridge 
National Institute of Population and Social Security Research (2017) 日本の将来推計人口 (平 成29年推計). Tokyo. Retrieved from http://www.ipss.go.jp/pp-zenkoku/j/zenkoku2017/pp29_ gaiyou.pdf

Nihon sousei kaigi [Japan Policy Council] (2014) Stoppu shoushika chihou genki senryaku (ス トップ少子化・地方元気戦略 Stop depopulation strategies for regional vitality). Tokyo. Retrieved from http://www.policycouncil.jp/

Niinuma S (2009) Considerations on the maintenance of village functions and the sustainability of residents' daily lives at "marginal settlements": the case of settlement M of Hinohara-Mura, Tokyo. EJ GEO 4(1):21-36. Retrieved from http://wwwsoc.nii.ac.jp/ajg/ejgeo/412136Niinuma. pdf

Nisbet MC, Mooney C (2007) Framing science. Science 316(5821):56. https://doi.org/10.1126/ science. 1142030

Noguchi K, Sato S, Kobayashi Y, Himeno Y, Siiba N, Terada M (2010) Classification and characteristics of village by living environment evaluation -living environment and the sphere in Saiki City, Part1- (in Japanese). The Japan Association of Economic Geographers, pp 3-4. Retrieved from http://ci.nii.ac.jp/els/110008112674.pdf?id=ART0009637691 andtype=pdfandlang=jpan dhost $=$ ciniiandorder_no $=$ andppv_type $=0$ andlang_sw $=$ andno $=1335239391$ andcp $=$

OECD (2004) Measuring sustainable development. Paris. Retrieved from http://www.oecd.org/ site/worldforum/33703829.pdf

OECD (2016) Population and migration estimates. OECD Factbook. OECD. https://doi. org/10.1093/oxfordhb/9780199589531.013.0035

Oldenburg R (1999) The great good place: cafes, coffee shops, bookstores, bars, hair salons, and other hangouts at the heart of a community, 3rd edn. Marlowe and Company, New York

Parnwell MJG (2007) Neolocalism and renascent social capital in Northeast Thailand. Environ Plann D 25(6):990-1014. https://doi.org/10.1068/d451t

Phillipson C, Scharf T (2005) Rural and urban perspectives on growing old: developing a new research agenda. Eur J Ageing 2(2):67-75. https://doi.org/10.1007/s10433-005-0024-7

Pierce J, Martin DG, Murphy JT (2011) Relational place-making: the networked politics of place. Trans Inst Br Geogr 36(1):54-70. https://doi.org/10.1111/j.1475-5661.2010.00411.x

Potter C, Tilzey M (2005) Agricultural policy discourses in the European post-Fordist transition: neoliberalism, neomercantilism and multifunctionality. Prog Hum Geogr 29(5):581-600. https://doi.org/10.1191/0309132505ph569oa

Price V, Nir L, Cappella JN (2005) Framing public discussion of gay civil unions. Public Opin Q 69(2):179-212. https://doi.org/10.1093/poq/nfi014

Project for Public Spaces (2016) Placemaking: what if we built our cities around places? New York. Retrieved from http://www.pps.org/wp-content/uploads/2016/10/Oct-2016-placemakingbooklet.pdf

Rametsteiner E, Pülzl H, Alkan-Olsson J, Frederiksen P (2011) Sustainability indicator development - science or political negotiation? Ecol Indic 11(1):61-70. https://doi.org/10.1016/j. ecolind.2009.06.009

Renting H, Rossing WAH, Groot JCJ, Van der Ploeg JD, Laurent C, Perraud D, Stobbelaar DJ, Van Ittersum MK (2009) Exploring multifunctional agriculture. A review of conceptual approaches and prospects for an integrative transitional framework. J Environ Manag Suppl 2(90):112123. https://doi.org/10.1016/j.jenvman.2008.11.014

Rigg J, Veeravongs S, Veeravongs L, Rohitarachoon P (2008) Reconfiguring rural spaces and remaking rural lives in Central Thailand. J Southeast Asian Stud 39(3):355-381. https://doi. org/10.1017/S0022463408000350

Sasaki H, Koyama K, Matsuura S (2007) 耕作放棄地の分布と潜在生産力の推定(Geographical distribution and potential grass productivity of abandoned cultivated land in Japan9). Jpn Soc Grassland Sci 53(3):189-194

Senno M (2013) 人口減少社会「元年」は, いつか? Jinkou genshou shakai 「gannen」ha, itsu $\mathrm{ka}$ ? (When was the first year of population declining society?) Retrieved January 10, 2014, from http://www.stat.go.jp/info/today/009.htm 
Shinobe H, Miyachi T (2012) Akiya no の解体除去施策の現状と課題-西日本の地方自治体 を事例として (The present conditions and problems of the demolition clearance policies of vacant houses). AIJ J Tech Design 18(39):709-714

Silverstein M, Cong Z, Li S (2006) Intergenerational transfers and living arrangements of older people in rural China: consequences for psychological well-being. J Gerontol Ser B Psychol Sci Soc Sci 61(5):S256-S266. Retrieved from http://www.ncbi.nlm.nih.gov/pubmed/16960239

Statistics Bureau (2017) Sekainotoukei 2017. Tokyo. Retrieved from http://www.stat.go.jp/data/ sekai/pdf/2017al.pdf\#page $=16$

Stevens C (2005) Measuring sustainable development. OECD statistics brief no. 10

Tacoli C (1998) Rural-urban interactions: a guide to the literature. Environ Urban 10(1):147-166. https://doi.org/10.1630/095624798101284356

Takegawa T (2010) 過疎農山村no okeru Koreisha no Seikatsu Jittai to Chiiki Fukushi no Kadai Tottori-ken Nichinann-cho ni okeru Seikatsu Jittai Chosa Hokoku. (A study of living conditions of elderly people in depopulating rural districts and challenges of community care: a survey report on living conditions in Nichinan Town, Tottori Prefecture). Tottori Univ J Fac Reg Sci 7(1):2-22

Tamasato E (2009) Kourei Shakai to Nouson Kouzou [高齢社会と農村構造 Aging society and structure of agricultural community]. Showadou, Kyoto

Tsutsui K, Ebihara Y, Zushi N, Sakuma Y (2008) Survey report on a rural community development internship program in Kawamata Town, Fukushima Prefecture (in Japanese). Tottori Univ J Fac Reg Sci 5(2):85-96

Wilson GA (2008) From 'weak' to 'strong' multifunctionality: conceptualising farm-level multifunctional transitional pathways. J Rural Stud 24(3):367-383. https://doi.org/10.1016/j. jrurstud.2007.12.010

Wilson GA (2010) Multifunctional 'quality' and rural community resilience. T I Brit Geogr 35(3):364-381. https://doi.org/10.1111/j.1475-5661.2010.00391.x

Wilson GA (2012) Community resilience and environmental transitions, 1st edn. Routledge, New York

Yamamoto S, Nakazono M (2008) Tottori-ken Nishi-no-shima-cho no chuukounen settai iju sokushin jigyo ni yoru akiya katsuyou jirei - Nouson chiiki ni okeru akiya katsuyou shisutemu ni kansuru kenkyuu [鳥取県西ノ島町の中高年接待移住促進事業による空 き家活用事例-農村地域における空き家活用システムに関する研究 Vacant house renovation by the migration promotion project for elderly in Nishinoshima-cho, Shimane Prefecture - study on the renovation system of vacant house in rural areas]. J Archit Plann 73(629):1485-1492

Open Access This chapter is licensed under the terms of the Creative Commons Attribution 4.0 International License (http://creativecommons.org/licenses/by/4.0/), which permits use, sharing, adaptation, distribution and reproduction in any medium or format, as long as you give appropriate credit to the original author(s) and the source, provide a link to the Creative Commons licence and indicate if changes were made.

The images or other third party material in this chapter are included in the chapter's Creative Commons licence, unless indicated otherwise in a credit line to the material. If material is not included in the chapter's Creative Commons licence and your intended use is not permitted by statutory regulation or exceeds the permitted use, you will need to obtain permission directly from the copyright holder.

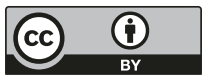

